\begin{tabular}{|c|c|c|c|}
\hline $\begin{array}{l}\text { RESEARCH } \\
\text { ARTICLE }\end{array}$ & $\begin{array}{r}\text { ADVANCE RESEAR } \\
\text { Volume } 8 \mid \text { Iss }\end{array}$ & $\begin{array}{l}\text { OCIAL SCIENCE } \\
\text { 1-6418 }\end{array}$ & \\
\hline $0=$ & DOI: 10.15740/HAS/ARJSS/8.1/9-14 & Visit us : www.researchjournal.co.in & \\
\hline
\end{tabular}

\title{
Effect of personal variables on thinking skills of institutionalized adolescents: An exploratory investigation
}

Anita*, Krishna Duhan and Varsha Saini

Department of Human Development and Family Studies, College of Home Science, C.C.S. Haryana Agricultural University, HISAR (HARYANA) INDIA

(Email: anitakandhal@yahoo.com; varshasaini90@gmail.com)

\section{ARTICLE INFO : \\ Received \\ Revised \\ 16.01.2017 \\ Accepted \\ 03.04.2017 \\ 17.04.2017 \\ KEY WORDS : \\ Institutionalized adolescents, Creative thinking, Critical thinking, Decision making skills, Problem solving skills, Personal variable}

HOW TO CITE THIS ARTICLE :

Anita, Duhan, Krishna and Saini, Varsha (2017). Effect of personal variables on thinking skills of institutionalized adolescents: An exploratory investigation. Adv. Res. J. Soc. Sci., 8 (1) : 9-14, DOI: 10.15740/HAS/ARJSS/8.1/9-14.

\begin{abstract}
The present study was conducted in Delhi and Haryana state. From Delhi, SOS (Save our Soul) village of Bawana and from Haryana, SOS village of Faridabad was selected purposively. The objective of the study was to assess the impact of personal variables on thinking skills of institutionalized adolescents. Separate lists of boys and girls in the age range of 13-19 years were prepared from both the SOS villages. Total of 200 adolescents (100 from SOS village Bawana and 100 from SOS village Faridabad) constituted the sample for the study to assess the existing thinking skills. From SOS village Bawana, 100 adolescents equally representing both the sexes i.e. 50 girls and 50 boys were selected on random basis. Same procedure was followed for SOS village Faridabad. The results revealed that age, gender and relationship with peers were significantly associated with thinking skills. Both boys and girls belonged to average category followed by below average category in thinking skills.
\end{abstract}

